\title{
Kebijakan Formulasi Hukum Pidana Terkait Wajib Menyalakan Lampu Utama pada Siang Hari Dalam Pasal 107 Ayat (2) Undang-Undang Nomor 22 Tahun 2009 Tentang Lalu Lintas dan Angkutan Jalan
}

\author{
Reza Iswanto ${ }^{1}$ \\ Fakultas Hukum Universitas Batanghari \\ Email : rezaiswanto17@gmail.com
}

\begin{abstract}
Abstrak. Kecelakaan lalu lintas sekarang ini terus terjadi di jalan raya sehingga tidak menutup kemungkinan memakan korban jiwa. Untuk itu, dikeluarkan Undang-Undang Nomor 22 Tahun 2009 Tentang Lalu Lintas Dan Angkutan Jalan sebagaimana perubahan atas Undang-Undang Nomor 14 Tahun 1992 Tentang Lalu Lintas Dan Angkutan Jalan. Di dalam Undang-Undang Nomor 22 Tahun 2009 Tentang Lalu Lintas Dan Angkutan Jalan ini ada pengaturan yang lebih khusus mengenai mewajibkan bagi pengendara sepeda motor untuk menghidupkan lampu utama kendaraan sepeda motornya pada saat siang hari yaitu Pasal 107 Ayat (2) Undang-Undang Nomor 22 Tahun 2009 Tentang Lalu Lintas Dan Angkutan Jalan. Latar belakang kebijakan formulasi hukum pidana Pasal 107 Ayat (2) Undang-Undang Nomor 22 Tahun 2009 Tentang Lalu Lintas Dan Angkutan Jalan adalah Undang-Undang Nomor 14 Tahun 1992 tentang Lalu Lintas dan Angkutan Jalan sudah tidak sesuai lagi dengan kondisi, perubahan lingkungan strategis dan kebutuhan penyelenggaraan Lalu Lintas dan Angkutan Jalan saat ini dan untuk mewujudkan keamanan dan menekan angka kecelakaan yang selalu meningkat setiap tahunnya. Namun, Implikasi dari Pasal 107 Ayat (2) Undang-Undang Nomor 22 Tahun 2009 Tentang Lalu Lintas Dan Angkutan Jalan adalah lebih besar kerugian yang didapatkan daripada manfaat yang dihasilkan. Oleh karena itu, kebijakan formulasi hukum pidana yang akan datang terkait Pasal 107 Ayat (2) Undang-Undang Nomor 22 Tahun 2009 Tentang Lalu Lintas Dan Angkutan Jalan adalah penghapusan Pasal 107 Ayat (2) Undang-Undang Nomor 22 Tahun 2009 Tentang Lalu Lintas Dan Angkutan Jalan. Untuk mendapatkan hasil dari penelitian ini, maka digunakan pendekatan hukum normatif dengan mengutamakan bahan pustaka atau data sekunder yang dilakukan dengan menganalisis Pasal 107 Ayat (2) Undang-Undang Nomor 22 Tahun 2009 Tentang Lalu Lintas Dan Angkutan Jalan kemudian dikaitkan dengan pendapat ahli.
\end{abstract}

Kata Kunci : Kebijakan Formulasi, Lampu Utama, Siang

Abstract. Current traffic accidents continue to occur on the highway so it does not rule out the possibility of casualties. For this reason, Law Number 22 Year 2009 concerning Traffic and Road Transportation has been issued as amended by Law Number 14 of 1992 concerning Road Traffic and Transportation. In Law Number 22 of 2009 concerning Road Traffic and Transportation there are more specific arrangements regarding requiring motorbike riders to turn on their main motorbike lights during the day, namely Article 107 Paragraph (2) of Law Number 22 2009 concerning Road Traffic and Transportation. The background of the policy on the formulation of criminal law Article 107 Paragraph (2) of Law Number 22 Year 2009 concerning Road Traffic and Transportation is that Law Number 14 of 1992 concerning Road Traffic and Transportation is no longer compatible with conditions, strategic environmental changes and the need to carry out Road Traffic and Transportation at this time and to realize security and reduce the number of accidents that always increase every year. However, the implication of Article 107 Paragraph (2) of Law Number 22 Year 2009 concerning Road Traffic and Transportation is the greater loss obtained than the benefits generated. Therefore, the impending formulation of criminal law policy related to Article 107 Paragraph (2) of Law Number 22 Year 2009 concerning Road Traffic and Transportation is the abolition of Article 107 Paragraph (2) Law Number 22 Year 2009 concerning Traffic and Road Transportation. To get the results of this study, the normative legal approach is used by prioritizing library materials or secondary data which is carried out by analyzing Article 107 Paragraph (2) of Law Number 22 Year 2009 concerning Road Traffic and Transportation and then associated with expert opinion.

Keywords: Policy Formulation, Main Light, Afternoon

PENDAHULUAN

${ }^{1}$ Dosen Fakultas Hukum Universitas Batanghari 
Sekarang ini akibat pesatnya kemajuan teknologi memberikan kemudahan kepada manusia untuk lebih cepat sampai ke tujuan atau dari tempat satu ke tempat lain dalam jangka waktu yang singkat dengan menggunakan kendaraan seperti sepeda motor dan mobil. Untuk itu, kendaraan sepeda motor dan mobil sangat dibutuhkan oleh manusia untuk melakukan aktivitasnya sehari-hari. Dengan demikian, wajar saja jumlah kendaraan seperti sepeda motor sangat banyak di dalam kehidupan masyarakat dan ditambah lagi sistem pembayaran sepeda motor tersebut dapat dicicil dengan harga yang masih dikategorkan mudah sehingga masyarakat dengan mudah untuk membeli sepeda motor tersebut.

Banyak kendaraan sepeda motor seperti sekarang ini yang ada di dalam masyarakat maka mendorong untuk pemerintah membuat suatu aturan hukum yag berhubungan dengan kendaraan sepeda motor tersebut yaitu aturan hukum mengenai lalu lintas di jalan raya sehingga dengan adanya aturan tersebut diharapkan kepada masyarakat untuk mengikuti aturan lalu lintas yang telah diterbitkan oleh pemerintah dan juga bertujuan untuk tidak melanggar hak orang lain dalam berlalu lintas di jalan raya. Oleh karena itu, pemerintah mengeluarkan suatu aturan hukum terkait dengan ketertiban dalam berlalu lintas di jalan raya. Adapun aturan hukum yang telah dikeluarkan oleh pemerintah dalam berkendara sepeda motor di jalan raya yaitu Undang-Undang Nomor 22 Tahun 2009 Tentang Lalu Lintas Dan Angkutan Jalan sebagaimana perubahan atas Undang-Undang Nomor 14 Tahun 1992 Tentang Lalu Lintas Dan Angkutan Jalan.

Dikeluarkannya Undang-Undang Nomor 22 Tahun 2009 Tentang Lalu Lintas Dan Angkutan Jalan tentu ada tujuannya seperti untuk ketertiban dalam berlalu lintas dan mencegah angka kecelaaan meningkat. Hal yang demikian juga diutarakan oleh Abintoro Prakoso bahwa tujuan akhir dari kebijakan kriminal ialah perlindungan masyarakat untuk mencapai tujuan utama misalnya kebahagiaan warga masyarakat/penduduk, kehidupan masyarakat yang sehat dan menyegarkan, kesejahteraan masyarakat atau untuk mencapai keseimbangan. $^{2}$

Dalam hal ini, tujuan dikeluarkannya Undang-Undang Nomor 22 Tahun 2009 Tentang Lalu Lintas Dan Angkutan Jalan karena lalu lintas dan angkutan jalan sebagai bagian dari sistem transportasi nasional harus dikembangkan potensi dan perannya untuk mewujudkan keamanan, keselamatan, ketertiban dan kelancaran berlalu lintas dan Angkutan Jalan dalam rangka mendukung pembangunan ekonomi dan pengembangan wilayah. Pernyataan yang demikian telah tercantum dalam hal menimbang di dalam Undang-Undang Nomor 22 Tahun 2009 Tentang Lalu Lintas Dan Angkutan Jalan.

Namun, pada kenyataannya seperti sekarang ini khususnya di Kota Jambi masih banyak para pengendara sepeda motor yang tidak mematuhi aturan hukum yang telah dibuat oleh pemerintah, dalam hal ini Undang-Undang Nomor 22 Tahun 2009 Tentang Lalu Lintas Dan Angkutan Jalan. Berbagai macam bentuk pelanggaran terjadi di jalan raya yang biasa dilakukan oleh pengendara sepeda motor Kota Jambi seperti tidak membawa Surat Izin Mengemudi (SIM), tidak membawa Surat Tanda Kendaraan Bermotor (STNK), tidak menggunakan helm Standar Nasional Indonesia (SNI), tidak menggunakan kaca spion pada kendaraan sepeda motornya, keadaan fisik kendaraan sepeda motor yang sudah dimodifikasi dan tidak menghidupkan lampu utama kendaraan sepeda motor pada siang hari.

Hal yang demikian dapat dibuktikan dengan adanya data yang dihimpun dari Ditlantas Polda Jambi pada tahun 2018 yang telah menunjukkan bahwa tahun 2018 ada 9.766 tilang, teguran 347 dengan jumlah 10.282 pengendara. Adapun barang bukti yang disita yaitu 3.583 Surat Izin Mengemudi (SIM), 5.164 Surat Tanda Kendaraan Bermotor (STNK) dan 1.020 kendaraan sepeda motor. Sementara dalam tahun 2018 pelanggaran lebih tinggi dari tahun 2017. Pada 2017 ada 7.964 tilang, teguran 347 dengan jumlah 8.311 pengendara. Adapun barang bukti yang disita berupa Surat Izin Mengemudi (SIM) sebanyak 1.603, Surat Tanda Kendaraan Bermotor (STNK) sebanyak 5.426 dan kendaraan bermotor sebanyak 935. ${ }^{3}$

Dengan demikian, apabila dilihat dari data Ditlantas Polda Jambi di atas maka dapat disimpulkan bahwa jenis pelanggaran yang dilakukan tindakan penilangan oleh Ditlantas Polda Jambi pada tahun 2018 berupa tidak membawa Surat Izin Mengemudi (SIM) dan Surat Tanda Kendaraan Bermotor (STNK). Tidak hanya itu saja, seringkali penulis melihat di jalan raya ditemukan masih banyak pengguna kendaraan sepeda

\footnotetext{
2 Abintoro Prakoso, Sosiologi Hukum, (Yogyakarta: Laksbang Grafika, 2017), halaman 250.

${ }^{3} \mathrm{http} / / /$ jambi.tribunnews.com/2018/11/07/ribuan-pengendara-sudah-terjaring-razia-polisi-hari-ke-delapan-operasi-zebra-
} 2018, Diakses tanggal 3 Februari 2019. 


\section{Reza Iswanto}

motor tidak menggunakan helm Standar Nasional Indonesia (SNI) terutama anak-anak muda dalam berkendara sepeda motor. Selain itu, menurut penulis masih banyak juga pengendara sepeda motor yang tidak menghidupkan menghidupkan lampu utama kendaraannya pada siang hari bahkan ada juga sebagian pengendara sepeda motor membuat kontak untuk mati hidupkan lampu sepeda motor tersebut sama layaknya seperti sepeda motor yang jenis lama karena pada jenis sepeda motor yang terbaru tidak ada kontak untuk mati hidupkan lampu kendaraan sepeda motor, dengan kata lain, lampu sepeda motor hidup terus walaupun disaat siang hari.

Mengingat kejadian yang telah terjadi dilapangan, hal ini telah membuktikan bahwa belum sepenuhnya aturan hukum yang dibuat oleh pemerintah dalam hal ini yaitu Undang-Undang Nomor 22 Tahun 2009 Tentang Lalu Lintas Dan Angkutan Jalan ditaati atau dipatuhi oleh masyarakat terutama masyarakat Kota Jambi. Untuk itu, diperlukan pembenahan kembali terhadap isi Undang-Undang Nomor 22 Tahun 2009 Tentang Lalu Lintas Dan Angkutan Jalan sehingga dapat diterapkan di dalam masyarakat Kota Jambi.

Kemudian dalam hal ini, terkait dengan wajib menyalakan lampu utama pada siang hari dalam Pasal 107 Ayat (2) Undang-Undang Nomor 22 Tahun 2009 Tentang Lalu Lintas Dan Angkutan Jalan dirasakan kurang bermanfaat karena dengan menyalakan lampu utama pada siang hari tentu tidak akan memberikan menfaat sebab lampu sepeda motor apabila dibandingkan dengan sinar matahari, lebih terang sinar matahari karena pada saat siang hari sinar matahari lebih panas daripada sore dan pagi hari. Selain itu juga, ada sebagian pendapat masyarakat menyatakan bahwa hidup maupun tidak hidup lampu utama kendaraan sepeda motor di siang hari tidak ada fungsinya bagi pengendara lain karena sinar matahari sudah terang jadi tidak perlu dihidupkan lagi lampu utama kendaraan sepeda motor, kalaupun tetap dihidupkan juga itu sama saja tidak percaya dengan kekuasaan sang pencipta.

Tidak hanya itu saja, sebenarnya kegunaan sinar lampu itu sendiri untuk menerangi ketika kita berada dalam keadaan gelap seperti memasuki terowongan, pada saat malam hari, cuaca buruk yaitu hujan deras ketika di jalan raya dan kabut asap yang pernah terjadi di Indonesia pada tahun 2017 yang lalu. Apabila tidak dalam keadaan yang darurat seperti yang telah dijelaskan di atas, tentu keadaan jalan terang karena sudah ada sinar matahari yang menerangi jalan raya. Ditambah lagi ketika diadakan razia oleh Kepolisian Lalu Lintas Kota Jambi, kebanyak aparat Kepolisian Lalu Lintas Kota Jambi hanya mengecek kelengkapan surat-surat kendaraan bermotor seperti Surat Izin Mengemudi (SIM) dan Surat Tanda Kendaraan Bermotor (STNK), sedangkan begi pengendara sepeda motor yang tidak menghidupkan lampu utama di siang hari hanya diberi teguran, tidak dikenakan tilang. Hal yang demikian harus diperhatikan juga apabila kita ingin menegakkan suatu aturan hukum di dalam masyarakat terutama masyarakat Kota Jambi.

Dengan demikian, apabila dilihat dari penjelasan di atas tentunya harus dilakukan pembenahan kembali pada Pasal 107 Ayat (2) Undang-Undang Nomor 22 Tahun 2009 Tentang Lalu Lintas Dan Angkutan Jalan terkait dengan mewajibkan bagi pengendara sepeda motor untuk menghidupkan lampu utama di siang hari. Hal yang senada juga dikemukakan oleh Barda Nawawi Arief bahwa kebijakan formulasi hukum pidana memang sepatutnya dikaji karena merupakan tahap yang paling strategis dari suatu upaya penanggulangan kejahatan melalui penal policy. ${ }^{4}$ Dengan demikian, untuk menciptakan suatu ketertiban dan keamanan dalam berlalu lintas maka diperlukan pengkajian kembali terhadap aturan hukum pidana itu sendiri khususnya pada Pasal 107 Ayat (2) Undang-Undang Nomor 22 Tahun 2009 Tentang Lalu Lintas Dan Angkutan Jalan.

Berdasarkan uraian yang terdapat pada latar belakang di atas, untuk itu penulis akan membatasi permasalahan yang akan dibahas dalam penelitian ini sebagai berikut :

1. Apakah yang menjadi latar belakang kebijakan formulasi hukum pidana terkait wajib menyalakan lampu utama pada siang hari dalam Pasal 107 Ayat (2) Undang-Undang Nomor 22 Tahun 2009 Tentang Lalu Lintas Dan Angkutan Jalan?

2. Apa implikasi dari wajib menyalakan lampu utama pada siang hari dalam Pasal 107 Ayat (2) UndangUndang Nomor 22 Tahun 2009 Tentang Lalu Lintas Dan Angkutan Jalan ?

${ }^{4}$ Kif Aminanto, Politik Hukum Pidana 1 Disparitas Putusan Hakim Dalam Tindak Pidana Korupsi, (Jember: Jember Katamedia, 2016), halaman 90. 
3. Bagaimana kebijakan formulasi hukum pidana yang akan datang terkait wajib menyalakan lampu utama pada siang hari dalam Pasal 107 Ayat (2) Undang-Undang Nomor 22 Tahun 2009 Tentang Lalu Lintas Dan Angkutan Jalan?

Kemudian tujuan dari penelitian ini sendiri yaitu untuk mengetahui latar belakang kebijakan formulasi hukum pidana terkait wajib menyalakan lampu utama pada siang hari dalam Pasal 107 Ayat (2) UndangUndang Nomor 22 Tahun 2009 Tentang Lalu Lintas Dan Angkutan Jalan, implikasi dari wajib menyalakan lampu utama pada siang hari dalam Pasal 107 Ayat (2) Undang-Undang Nomor 22 Tahun 2009 Tentang Lalu Lintas Dan Angkutan Jalan dan kebijakan formulasi hukum pidana yang akan datang terkait wajib menyalakan lampu utama pada siang hari dalam Pasal 107 Ayat (2) Undang-Undang Nomor 22 Tahun 2009 Tentang Lalu Lintas Dan Angkutan Jalan.

\section{METODE PENELITIAN}

Untuk mencapai tujuan yang dinginkan secara objektif maka penulis memerlukan metode penelitian secara konsisten. Menurut Peter R. Senn, metode merupakan suatu prosedur atau cara mengetahui sesuatu dengan menggunakan langkah-langkah yang sistematis. Dengan demikian, metode penelitian merupakan uraian teknis yang digunakan dalam penelitian. ${ }^{5}$ Adapun metode penelitian yang digunakan dalam penelitian ini adalah sebagai berikut :

1. Metode pendekatan

Sebelum membahasa metode pendekatan, penulis terlebih dahulu menjelaskan bahwa tipe penelitian ini adalah penelitian hukum normatif. Penelitian hukum normatif pada hakikatnya nya mengkaji hukum yang dikonsepkan sebagai norma atau kaidah yang berlaku dalam masyarakat dan menjadi acuan perilaku setiap orang. ${ }^{6}$

Sumber utama penelitian hukum normatif adalah bahan hukum bukan data atau fakta sosial karena dalam penelitian hukum normatif yang dikaji adalah bahan hukum yang berisi aturan-aturan yang bersifat normatif. ${ }^{7}$ Untuk itu, penelitian hukum normatif disebut juga penelitian hukum kepustakaan, penelitian hukum teoritis/dogmatis. ${ }^{8}$ Dengan demikian, mengingat penelitian ini menggunakan tipe penelitian yaitu penelitian hukum normatif, maka penelitian ini dilakukan dengan cara menganalisis isi dalam Pasal 107 Ayat (2) Undang-Undang Nomor 22 Tahun 2009 Tentang Lalu Lintas Dan Angkutan Jalan.

Apabila dilihat dari tipe penelitian di atas dengan menggunakan penelitian hukum normatif, maka pendekatan yang digunakan dalam penelitian ini adalah pendekatan perundang-undangan. Pendekatan undang-undang atau statuta aproach dan sebagian ilmuwan hukum menyebutnya dengan pendekatan yuridis, yaitu penelitian terhadap produk-produk hukum. ${ }^{9}$ Oleh karena itu, dalam penelitian ini peneliti lebih menitikberatkan pada produk hukum, dalam hal ini adalah isi Pasal 107 Ayat (2) Undang-Undang Nomor 22 Tahun 2009 Tentang Lalu Lintas Dan Angkutan Jalan.

2. Rancangan kegiatan

Dalam penelitian hukum normatif ini rancangan kegiatannya adalah menganalisis langsung produk hukum yang berlaku di dalam masyarakat. Hal yang sama juga dikemukakan oleh Meuwissen bahwa bersifat analitis artinya tidak semata-mata menjelaskan, akan tetapi juga memaparkan dan menganalisis isi dan struktur hukum positif yang berlaku. ${ }^{10}$

Dengan demikian, dalam penelitian penelitian hukum normatif ini sudah jelas bahwa rancangan kegiatan yang dilakukan oleh peneliti adalah menganalisis isi dari Pasal 107 Ayat (2) Undang-Undang Nomor 22 Tahun 2009 Tentang Lalu Lintas Dan Angkutan Jalan terkait wajib menyalakan lampu utama pada siang hari.

3. Ruang lingkup atau objek

\footnotetext{
${ }^{5}$ Bahder Johan Nasution, Metode Penelitian Ilmu Hukum, (Bandung : CV. Mandar Maju, 2016), halaman 3.

${ }^{6}$ Ishaq, Metode Penelitian Hukum, (Bandung : Alfabeta, 2017), halaman 66.

${ }^{7}$ Bahder Johan Nasution, Op.Cit, halaman 86.

${ }^{8}$ Ishaq, Op.Cit, halaman 66.

9 Bahder Johan Nasution, Op.Cit, halaman 92.

${ }^{10}$ Ibid, halaman 91.
} 
Objek atau fokus kajian penelitian hukum normatif menurut Soerjono Soekanto dan Sri Mamuji terdiri atas : ${ }^{11}$

a. Penelitian terhadap asas-asas hukum.

b. Penelitian terhadap sistematika hukum.

c. Penelitian terhadap taraf sinkronisasi hukum.

d. Penelitian sejarah hukum, dan

e. Penelitian perbandingan hukum.

Dengan demikian, ruang lingkup atau objek dalam penelitian hukum normatif ini adalah penelitian terhadap asas-asas hukum yaitu dasar falsafah dari Pasal 107 Ayat (2) Undang-Undang Nomor 22 Tahun 2009 Tentang Lalu Lintas terkait wajib menyalakan lampu utama pada siang hari.

4. Bahan dan alat utama

Bahan yang diteliti pada penelitian hukum normatif adalah bahan pustaka atau data sekunder. Bahan pustaka merupakan bahan yang berasal dari sumber primer dan sumber sekunder. ${ }^{12}$ Bahan-bahan hukum tersebut terdiri dari :

a. Bahan hukum primer yaitu peraturan perundang-undangan, yurisprudensi, traktat, convensi yang sudah diratifikasi, perjanjian-perjanjian keperdataan para pihak dan sebagainya. ${ }^{13}$

b. Bahan hukum sekunder

Buku-buku ilmu hukum, jurnal ilmu hukum, laporan penelitian ilmu hukum, artikel ilmiah hukum dan bahan seminar, lokakarya dan sebagainya. ${ }^{14}$

Dengan demikian, sumber bahan pustaka atau data sekunder dalam penelitian hukum normatif ini adalah menganalisis terhadap peraturan perundang-undangan yaitu isi dalam Pasal 107 Ayat (2) UndangUndang Nomor 22 Tahun 2009 Tentang Lalu Lintas, sedangkan alat utama dalam penelitian hukum normatif ini adalah menggunakan buku-buku ilmu hukum dan artikel ilmiah hukum.

5. Teknik pengumpulan data

Pengumpulan data dalam penelitian hukum normatif terdapat 3 (tiga) jenis metode pengumpulan data sekunder, yaitu studi pustaka, dokumen dan studi arsip. ${ }^{15}$ Pengertian dokumen menurut Poerwadarminta adalah sesuatu yang tertulis atau tercetak, yang dapat dipakai sebagai bukti atau keterangan. ${ }^{16}$

Dengan demikian, teknik pengumpulan data dalam penelitian hukum normatif ini adalah menggunakan dokumen yang berkaitan dengan Pasal 107 Ayat (2) Undang-Undang Nomor 22 Tahun 2009 Tentang Lalu Lintas mengenai wajib menyalakan lampu utama pada siang hari

6. Teknik analisis

Analisis data yang digunakan dalam penelitian hukum normatif adalah analisis kualitatif, yakni analisis data dengan cara menguraikan data secara bermutu dalam bentuk kalimat yang teratur, runtun, logis dan efektif sehingga memudahkan interprestasi data dan pemahaman hasil analisis. ${ }^{17}$

Oleh karena itu, teknik analisis dalam penelitian hukum normatif ini adalah menguraikan hasil dari analisis dalam bentuk kalimat tentang kebijakan formulasi hukum pidana terkait wajib menyalakan lampu utama pada siang hari dalam Pasal 107 Ayat (2) Undang-Undang Nomor 22 Tahun 2009 Tentang Lalu Lintas Dan Angkutan Jalan

\section{HASIL DAN PEMBAHASAN}

Latar Belakang Kebijakan Formulasi Hukum Pidana Terkait Wajib Menyalakan Lampu Utama Pada Siang Hari Dalam Pasal 107 Ayat (2) Undang-Undang Nomor 22 Tahun 2009 Tentang Lalu Lintas Dan Angkutan Jalan

\footnotetext{
${ }^{11}$ Ishaq, Op.Cit, halaman 66.

12 Ibid, halaman 66-67.

${ }^{13}$ Bahder Johan Nasution, Op.Cit, halaman 86.

${ }^{14}$ Ibid.

${ }^{15}$ Ishaq, Op.Cit, halaman 69.

${ }^{16}$ Bahder Johan Nasution, Op.Cit, halaman 104.

${ }^{17}$ Ishaq, Op.Cit, halaman 69.
} 
Sejak dahulu sampai sekarang ini permasalahan dalam berlalu lintas khususnya terhadap pengendara sepeda motor di Kota Jambi tidak kunjung selesai. Permasalahan dalam berlalu lintas yang sering dilakukan oleh pengendara sepeda motor khususnya di Kota Jambi yaitu tidak menggunakan helm Standar Nasional Indonesia (SNI) dalam berkendara sepeda motor, melanggar atau menyerobot lampu lalu lintas atau biasa yang disebut dengan lampu merah, pengendara sepeda motor berhenti tepat di zebra cross yang sebenarnya diperuntukkan untuk pejalan kaki, pengendara sepeda motor memutar balik sepeda motornya yang sudah jelas-jelas sudah ada palang lalu lintas yang melarang untuk memutar balik kendaraan tersebut, pengendara sepeda motor tidak menggunakan kaca spion lengkap atau hanya menggunakan satu kaca spion saja dalam berkendara sepeda motor di jalan raya, tidak membawa Surat Izin Mengemudi (SIM) dan surat-surat kelengkapan kendaraan lainnya yaitu Surat Tanda Kendaraan Bermotor (STNK) serta masih banyak pelanggaran-pelanggaran lainnya yang dilakukan oleh pengendara sepeda motor di Kota Jambi.

Pelanggaran yang demikian tentunya akan merugikan pengendara sepeda motor lain dalam berkendara di jalan raya karena akibat dari pengendara sepeda motor yang tidak mematuhi peraturan lalu lintas tersebut sehingga mengakibatkan kecelakaan di jalan raya yang akan menimbulkan kemacetan yang begitu panjang. Oleh karena itu, untuk meminimalisir tingkat kecelakaan yang sering terjadi maka pemerintah mengeluarkan suatu aturan dalam berlalu lintas yaitu mengeluarkan Undang-Undang Nomor 22 Tahun 2009 Tentang Lalu Lintas Dan Angkutan Jalan.

Selain pengaturan tentang penggunaan helm Standar Nasional Indonesia (SNI) dan harus membawa Surat Izin Mengemudi (SIM) sebagai bukti jika pengendara sepeda motor sudah cukup umur dalam berkendara sepeda motor di jalan raya. Ada salah satu aturan dalam Undang-Undang Nomor 22 Tahun 2009 Tentang Lalu Lintas Dan Angkutan Jalan yang menjadi perdebatan dalam masyarakat sampai sekarang ini. Adapun aturan yang dimaksud dalam Undang-Undang Nomor 22 Tahun 2009 Tentang Lalu Lintas Dan Angkutan Jalan adalah Pasal 107 Ayat (2) Undang-Undang Nomor 22 Tahun 2009 Tentang Lalu Lintas Dan Angkutan Jalan yang berisikan bahwa pengemudi sepeda motor selain mematuhi ketentuan sebagaimana dimaksud pada ayat (1) wajib menyalakan lampu utama pada siang hari.

Hal ini tentunya menjadi sorotan dalam masyarakat karena banyak masyarakat berpandangan bahwa tidak ada gunanya untuk menghidupkan lampu utama pada siang hari dikarenakan ketika siang hari pancaran dari sinar matahari begitu terang, walaupun dihidupkan lampu utama pada kendaraan sepeda motor tidak akan memberikan manfaat bagi pengendara yang lainnya ataupun pengendara yang berlawanan arah.

Namun, pemikiran dari pemerintah yang membuat Undang-Undang Nomor 22 Tahun 2009 Tentang Lalu Lintas Dan Angkutan Jalan tersebut berbeda dengan pandangan masyarakat terkait pengendara sepeda motor untuk wajib menyalakan lampu utama pada siang hari. Dalam hal ini telah dijelaskan dalam pertimbangan pada huruf b Undang-Undang Nomor 22 Tahun 2009 Tentang Lalu Lintas Dan Angkutan Jalan yang berbunyi bahwa Lalu Lintas dan Angkutan Jalan sebagai bagian dari sistem transportasi nasional harus dikembangkan potensi dan perannya untuk mewujudkan keamanan, keselamatan, ketertiban dan kelancaran berlalu lintas dan Angkutan Jalan dalam rangka mendukung pembangunan ekonomi dan pengembangan wilayah. Dengan demikian, dapat dikatakan bahwa tujuan dikeluarkan Undang-Undang Nomor 22 Tahun 2009 Tentang Lalu Lintas Dan Angkutan Jalan oleh pemerintah adalah untuk meningkatkan keamanan dalam berlalu lintas di jalan raya karena mengingat tingginya tingkat kecelakaan yang terjadi di jalan raya terutama bagi pengendara sepeda motor.

Jika kita melihat Undang-Undang sebelumnya yakni Undang-Undang Nomor 14 Tahun 1992 menyebutkan bahwa untuk mencapai tujuan pembangunan nasional sebagai pengamalan Pancasila, transportasi memiliki posisi yang penting dan strategis dalam pembangunan bangsa yang berwawasan lingkungan dan hal ini harus tercermin pada kebutuhan mobilitas seluruh sektor dan wilayah. ${ }^{18}$ Hal ini tentu terdapat perbedaan yang signifikan apabila dilihat antara Undang-Undang Nomor 14 Tahun 1992 dengan Undang-Undang Nomor 22 Tahun 2009 Tentang Lalu Lintas Dan Angkutan Jalan. Salah satu perbedaa yang terdapat dalam kedua Undang-Undang tersebut adalah adanya pengaturan yang mewajibkan bagi pengendara sepeda motor untuk menghidupkan lampu utama di siang hari. Dimana aturan tersebut telah

\footnotetext{
${ }^{18} \mathrm{https} / / / \mathrm{www}$. bantuanhukum.or.id/web/implementasi-undang-undang-nomor-22-tahun-2009-tentang-lalu-lintas-danangkutan-jalan-raya/, Diakses tanggal 3 Februari 2019.
} 
diatur dalam Pasal 107 Ayat (2) Undang-Undang Nomor 22 Tahun 2009 Tentang Lalu Lintas Dan Angkutan Jalan. Dengan adanya aturan tersebut maka bagi pengendara sepeda motor yang tidak menghidupkan lampu utama pada siang hari akan dikenakan sanksi pidana. Oleh karena itu, dikeluarkannya Pasal 107 Ayat (2) Undang-Undang Nomor 22 Tahun 2009 Tentang Lalu Lintas Dan Angkutan Jalan merupakan suatu kebijakan formulasi yang dilakukan oleh pemerintah dalam meningkatkan keamanan dan keselamatan dalam berlalu lintas.

Adapun maksud dari kebijakan formulasi itu sendiri adalah suatu bentuk perumusan perbuatan pidana yang dituangkan sebagai ketentuan pidana. ${ }^{19}$ Adapun bentuk perumusan perbuatan pidana di dalam Pasal 107 Ayat (2) Undang-Undang Nomor 22 Tahun 2009 Tentang Lalu Lintas Dan Angkutan Jalan adalah pengendara sepeda motor wajib menghidupkan lampu utama di siang hari, apabila tidak menghidupkan lampu utama di siang hari maka akan dikenakan sanksi pidana yang terdapat Pasal 293 ayat (2) UndangUndang Nomor 22 Tahun 2009 Tentang Lalu Lintas Dan Angkutan Jalan yaitu berupa sanksi pidana kurungan paling lama 15 (lima belas) hari dan sanksi pidana denda paling banyak Rp100.000,00 (seratus ribu rupiah). Menurut Eko Budi S dalam jurnalnya tentang kebijakan hukum terhadap tindak pidana penangkapan ikan secara ilegal di perairan Indonesia, beliau menyatakan bahwa pada dasarnya pemidanaan dapat diartikan sebagai penjatuhan pidana oleh hakim yang merupakan konkritisasi atau realisasi dari ketentuan pidana dalam undang-undang yang merupakan sesuatu yang abstrak. ${ }^{20}$

Apabila dilihat dari pengaturan yang terdapat pada Pasal 107 ayat (2) Undang-Undang Nomor 22 Tahun 2009 Tentang Lalu Lintas Dan Angkutan Jalan maka dapat disimpulkan bahwa dalam pasal tersebut terkandung unsur wajib. Oleh karena itu, dapat dikatakan bahwa unsur wajib dalam Pasal 107 ayat (2) Undang-Undang Nomor 22 Tahun 2009 Tentang Lalu Lintas Dan Angkutan Jalan ini adalah mau tidak mau kepada pengendara sepeda motor harus menghidupkan lampu utama pada siang hari. Akibat dari unsur wajib dalam Pasal tersebut, apabila pengendara sepeda motor tidak mau menghidupkan lampu utama pada saat berkendara sepeda motor di siang hari maka akan dikenakan sanksi pidana yang terdapat dalam Pasal 293 ayat (2) Undang-Undang Nomor 22 Tahun 2009 Tentang Lalu Lintas Dan Angkutan Jalan. Dengan demikian, tujuan kebijakan formulasi dari Pasal 107 ayat (2) Undang-Undang Nomor 22 Tahun 2009 Tentang Lalu Lintas Dan Angkutan Jalan tersebut adalah untuk mendidik agar pengguna sepeda motor mematuhi dan mentaati aturan yang telah dibuat oleh pemerintah yang berwenang dan telah diberlakukan di dalam masyarakat.

Kebijakan legislatif sering juga disebut dengan istilah kebijakan formulatif. ${ }^{21}$ Lemaire berpendapat bahwa politik hukum merupakan bagian dari kebijakan legislatif. Politik hukum mengkaji bagaimana penetapan hukum yang seharusnya (Ius constituendum). ${ }^{22}$ Oleh karena itu, terkaid dengan Pasal 107 ayat (2) Undang-Undang Nomor 22 Tahun 2009 Tentang Lalu Lintas Dan Angkutan Jalan maka politik hukum pidana yang telah dilakukan oleh pemerintah adalah pemerintah melihat terlebih dahulu aturan hukum sebelum Undang-Undang Nomor 22 Tahun 2009 Tentang Lalu Lintas Dan Angkutan Jalan yaitu UndangUndang Nomor 14 Tahun 1992, kemudian melihat perkembangan kecelakaan yang terjadi di dalam masyarakat, ternyata Undang-Undang Nomor 14 Tahun 1992 Tentang Lalu Lintas Dan Angkutan Jalan tidak dapat meminimalisir tingkat kecelakaan yang terjadi di dalam masyarakat sehingga dikeluarkannya UndangUndang Nomor 22 Tahun 2009 Tentang Lalu Lintas Dan Angkutan Jalan.

Selain itu juga, alasan dikeluarkannya Undang-Undang Nomor 22 Tahun 2009 Tentang Lalu Lintas Dan Angkutan Jalan ini karena Undang-Undang Nomor 14 Tahun 1992 tentang Lalu Lintas dan Angkutan Jalan sudah tidak sesuai lagi dengan kondisi, perubahan lingkungan strategis dan kebutuhan penyelenggaraan Lalu Lintas dan Angkutan Jalan saat ini.

${ }^{19}$ AR. Sujono dan Bony Daniel, Komentar dan Pembahasan Undang-Undang Nomor 35 Tahun 2009 Tentang Narkotika, (Jakarta: Sinar Grafik, 2011), halaman 211.

${ }^{20}$ Eko Budi S, Kebijakan Hukum terhadap Tindak Pidana Penangkapan Ikan Secara Ilegal di Perairan Indonesia, Jurnal Wajah Hukum, Volume 2 Nomor 2 (Oktober 2018), halaman 200.

${ }^{21}$ Barda Nawawi Arief, Bunga Rampai Kebijakan Hukum Pidana (Perkembangan Penyusunan Konsep KUHP Baru), (Jakarta: Kencana, 2008), halaman 213.

${ }^{22}$ Siswanto S, politik hukum dalam undang-undang narkotika (UU Nomor 35 Tahun 2009), (Jakarta: Rineka Cipta, 2012), halaman 213. 
Kemudian menurut Utrecht bahwa politik hukum meneliti perubahan-perubahan, apa yang harus diadakan dalam hukum yang sekarang berlaku, supaya menjadi sesuatu dengan sociale werkelijkheid (kenyataan sosial). ${ }^{23}$ Untuk itu, pada dasarnya dikeluarkannya Pasal 107 ayat (2) Undang-Undang Nomor 22 Tahun 2009 Tentang Lalu Lintas Dan Angkutan Jalan tersebut bertujuan untuk menekan angka kecelakaan yang selalu meningkat setiap tahunnya, sebab secara faktual penerapan aturan ini terbukti mampu menekan angka kecelakaan lalu lintas. ${ }^{24}$

Dengan demikian, latar belakang kebijakan formulasi hukum pidana terkait wajib menyalakan lampu utama pada siang hari dalam Pasal 107 Ayat (2) Undang-Undang Nomor 22 Tahun 2009 Tentang Lalu Lintas Dan Angkutan Jalan adalah Undang-Undang Nomor 14 Tahun 1992 tentang Lalu Lintas dan Angkutan Jalan sudah tidak sesuai lagi dengan kondisi, perubahan lingkungan strategis dan kebutuhan penyelenggaraan Lalu Lintas dan Angkutan Jalan saat ini dan untuk mewujudkan keamanan, keselamatan, ketertiban dan kelancaran berlalu lintas dan Angkutan Jalan serta menekan angka kecelakaan yang selalu meningkat setiap tahunnya.

\section{Implikasi Dari Wajib Menyalakan Lampu Utama Pada Siang Hari Dalam Pasal 107 Ayat (2) Undang- Undang Nomor 22 Tahun 2009 Tentang Lalu Lintas Dan Angkutan Jalan}

Dalam Pasal 107 Ayat (2) Undang-Undang Nomor 22 Tahun 2009 Tentang Lalu Lintas Dan Angkutan Jalan berbunyi bahwa pengemudi sepeda motor selain mematuhi ketentuan sebagaimana dimaksud pada ayat (1) wajib menyalakan lampu utama pada siang hari. Dalam Pasal ini terdapat kata wajib, dimana ada unsur paksaan terhadap pengendara sepeda motor dalam mengendarai sepeda motornya di jalan raya.

Apabila tidak ditaati oleh pengendara sepeda motor tersebut maka pengendara sepeda motor itu akan mendapatkan sanksi pidana berupa pidana kurungan paling lama 15 (lima belas) hari dan sanksi pidana denda paling banyak Rp100.000,00 (seratus ribu rupiah). Dengan demikian, dapat dikatakan bahwa mau tidak mau pengendara sepeda motor memang harus menghidupkan lampu utama pada saat diang hari ketika berkendara sepeda motor di jalan raya.

Namun, pada kenyataannya masih banyak kendara sepeda motor yang tidak menghidupkan lampu utamanya pada saat siang hari, bahkan ada juga sebagian dari pengendara sepeda motor memang sengaja untuk membuat stop kontak untuk dapat mematikan dan menghidupkan lampu sehingga pada saat siang hari lampu kendaraan sepeda motornya dapat dimatikan.

Hal yang demikian, tentu tidak sesuai dengan anjuran yang telah dikemukakan dalam Pasal 107 Ayat (2) Undang-Undang Nomor 22 Tahun 2009 Tentang Lalu Lintas Dan Angkutan Jalan yang mewajibkan pengendara sepeda motor untuk menghidupkan lampu utama kedaraannya pada saat siang hari. Akan tetapi, walaupun sudah terjadi seperti hal mematikan lampu utaman kendaraan sepeda motor pada saat siang hari, sanksi pidana tetap tidak dikenakan terhadap pengendara sepeda motor yang melanggar aturan Pasal 107 Ayat (2) Undang-Undang Nomor 22 Tahun 2009 Tentang Lalu Lintas Dan Angkutan Jalan tersebut.

Kemudian tujuan diterbitkannya Pasal 107 Ayat (2) Undang-Undang Nomor 22 Tahun 2009 Tentang Lalu Lintas Dan Angkutan Jalan ini oleh pemerintah adalah untuk meminimalisi tingkat kecelakaan di jalan raya. Pendapat yang demikian tidak bisa diterima sepenuhnya karena belum tentu dengan menghidupkan lampu utama kendaraan sepeda motor di siang hari dapat meminimalisir kecelakaan di jalan raya sebab kecelakaan di jalan raya tidak hanya terjadi dengan tidak menghidupkan lampu utama kendaraan sepeda motor di siang hari saja, kebut-kebutan di jalan raya juga dapat mengakibatkan kecelakaan di jalan raya, belum lagi pengendara sepeda motor yang melanggar atau menerobos lampu lalu lintas tentu akan mengakibatkan kecelakaan di jalan raya dan masih banyak cara lain yang dapat mengakibatkan terjadinya kecelakaan di jalan raya.

Sementara itu, walaupun lampu utama pada kendaraan sepeda motor tidak dihidupkan di siang hari pada saat berkendara sepeda motor tidak akan juga mengakibatkan kecelakaan kecuali dalam keadaan tertentu seperti kabut asap dan keadaan hujan lebat. Namun, keadaan tertentu tersebut telah diatur dalam

\footnotetext{
${ }^{23}$ Ibid, halaman 61.

${ }^{24}$ P. Suwardjoko Warpani, Pengelola Lalu lintas dan Angkutan Jalan, (Bandung: ITB, 2010), halaman 2.
} 
Pasal 107 Ayat (1) Undang-Undang Nomor 22 Tahun 2009 Tentang Lalu Lintas Dan Angkutan Jalan. Oleh karena itu, untuk apa adanya pengaturan kembali penghidupan lampu utama kendaraan sepeda motor di siang hari yang terdapat dalam Pasal 107 Ayat (2) Undang-Undang Nomor 22 Tahun 2009 Tentang Lalu Lintas Dan Angkutan Jalan tersebut.

Kemudian perlu kita ingat kembali bahwa apabila menghidupkan lampu utama pada kendaraan sepeda motor di siang hari dan pada saat cuaca siang hari begitu panas, tentu hal yang sangat tidak wajar apabila menghidupkan lampu utama pada kendaraan sepeda motor tersebut karena sinar lampu utama yang dikeluarkan oleh sepeda motor itu sendiri tidak begitu terang jika dibandingkan dengan pancaran sinar matahar yang begitu menyengat kulit kita.

Tidak hanya itu saja, sinar matahari dapat melihat secara langsung objek yang berada di depan pengendara sepeda motor sehingga pengendara sepeda motor tersebut dapat menghindari apabila ada objek yang menghalangi jalannya seperti adanya batu dan lubang di jalan. Oleh karena itu, apabila kita tetap menghidupkan lampu utama kendaraan sepeda motor di siang hari itu sama saja dengan tidak mengakui adanya kebesaran yang maha kuasa berikan kepada kita karena sang pencipta telah menciptakan siang dan malam yang tentunya ada manfaatnya bagi manusia itu sendiri.

Kemudian ada juga yang berpendapat bahwa menghidupkan lampu utama pada kendaraan sepeda motor di siang hari dapat memberikan peringatan terhadap lawan arah untuk mengetahui bahwa dari arah yang berlawanan ada pengendara sepeda motor lain yang sedang berlaju. Hal yang demikian, tentu tidak dapat diterima oleh akal pikiran karena di tengah jalan raya telah ada pembatas antara pengendara yang satu dengan pengendara yang berlawan arah. Pembatas tengah di jalan raya tersebut dapat berupa batu dinding, garis berwarna putih, bahkan di kota-kota sudah ada taman kecil di tengah jalan raya.

Untuk itu, sangat tidak masuk logika jika menghidupkan lampu utama kendaraan sepeda motor di siang hari dengan alasan supaya lawan arah mengetahui dan tidak mengambil jalan milik pengendara lain karena sudah jelas bahwa sudah ada pembatas yang ada di tengah jalan raya itu sendiri dan pembatas tersebut telah disediakan oleh pemerintah itu sendiri.

Selanjutnya, apabila pengendara sepeda motor menghidupkan lampu utama di siang hari pada saat berkendara sepeda motor di jalan raya tentu akan mudah cepat menghabiskan aki sepeda motor itu sendiri. Dengan semakin lama menghidupkan lampu utama kendaraan sepeda motor tersebut maka akan banyak menggunakan aki sehingga aki cepat habis. Mengingat hal yang demikian, tentu sangat disayangkan karena mayoritas masyarakat Jambi berpenghasilan dibawah rata-rata. Hal ini tentu menyulitkan bahkan membuat sengsara masyarakat Jambi yang berpenghasilan dibawah rata-rata sebab mereka harus mengeluarkan uang untuk membeli aki sepeda motor mereka karena jika tidak dibeli aki kendaraan sepeda motor tersebut tentu masyarakat Jambi akan merasa kesulitan jika berkendara sepeda motor di malam har karena sangat membutuhkan sinar lampu kendaraan untuk melihat keadaa di depan jalan.

Denga demikian, sudah jelas bahwa dikeluarkannya Pasal 107 Ayat (2) Undang-Undang Nomor 22 Tahun 2009 Tentang Lalu Lintas Dan Angkutan Jalan ini bukan mensejahterakan masyarakat Jambi, malah sebaliknya membuat masyarakat Jambi lebih sengsara dengan perekonomian yang semakin sulit seperti sekarang ini. Tidak menutup kemungkinan akan menimbulkan jenis kejahatan baru seperti mencuri aki sepeda motor orang lain. Untuk itu, hal yang demikian telah melanggar isi dari ketentuan Undang-Undang Nomor 22 Tahun 2009 Tentang Lalu Lintas Dan Angkutan Jalan itu sendiri yaitu dalam hal menimbang pada huruf $b$ yang pada intinya bahwa dalam rangka mendukung pembangunan ekonomi dan pengembangan wilayah.

Jadi, implikasi dari wajib menyalakan lampu utama pada siang hari dalam Pasal 107 Ayat (2) UndangUndang Nomor 22 Tahun 2009 Tentang Lalu Lintas Dan Angkutan Jalan adalah lebih besar kerugian yang didapatkan daripada manfaat yang dihasilkan dari wajib menyalakan lampu utama pada siang hari bagi pengendara sepeda motor pada saat berjalan di jalan raya.

\section{Kebijakan Formulasi Hukum Pidana Yang Akan Datang Terkait Wajib Menyalakan Lampu Utama Pada Siang Hari Dalam Pasal 107 Ayat (2) Undang-Undang Nomor 22 Tahun 2009 Tentang Lalu Lintas Dan Angkutan Jalan}


Tujuan dikeluarkannya Pasal 107 Ayat (2) Undang-Undang Nomor 22 Tahun 2009 Tentang Lalu Lintas Dan Angkutan Jalan ini dengan maksud untuk meminimalisir tingkat kecelakaan yang terjadi di jalan raya. Tujuan yang demikian tidak disalahkan karena harus berbagai upaya yang dilakukan untuk menekan angka kecelakaan guna untuk memberikan keamanan dan keselamatan bagi pengendara sepeda motor di jalan raya.

Hal ini sesuai dengan tujuan hukum pidana itu sendiri karena hukum pidana ditujukan untuk melindungi masyarakat terhadap tindak pidana yang menimbulkan kerugian atau setidak-tidaknya membahayakan Kepentingan hukum. ${ }^{25}$ Dengan demikian, dalam hal ini tujuan Pasal 107 Ayat (2) UndangUndang Nomor 22 Tahun 2009 Tentang Lalu Lintas Dan Angkutan Jalan untuk melindungi dan memberikan keselamatan kepada pengendara sepeda motor Di jalan raya sehingga memberi rasa aman dalam berkendara sepeda motor di jalan raya.

Disebutkan oleh Sudarto bahwa melaksanakan politik hukum pidana berarti mengadakan pilihan untuk mencapai hasil perundang-undangan pidana yang paling baik dalam arti memenuhi syarat keadilan dan daya guna. ${ }^{26}$ Apabila dilihat dari isi Pasal 107 Ayat (2) Undang-Undang Nomor 22 Tahun 2009 Tentang Lalu Lintas Dan Angkutan Jalan ini yang mana mewajibkan bagi pengendara sepeda motor untuk menghidupkan lampu utama pada siang hari dalam berkendara sepeda motor tidak memiliki daya guna terutama untuk menekan kecelakaan yang terjadi di jalan raya karena walaupun tidak menghidupkan lampu utama pada kendaraan sepeda motor di jalan raya masih tetap saja terjadi kecelakaan di jalan raya.

Kemudian menurut Sudarto perbuatan yang diusahakan untuk dicegah atau ditanggulangi dengan hukum pidana harus merupakan perbuatan yang tidak dikehendaki, yaitu perbuatan yang mendatangkan kerugian. ${ }^{27}$ Jika kita melihat dari isi Pasal 107 Ayat (2) Undang-Undang Nomor 22 Tahun 2009 Tentang Lalu Lintas Dan Angkutan Jalan ini perbuatan yang tidak dikehendaki tersebut tidak ada mendatangkan kerugian, justru sebaliknya apabila aturan Pasal 107 Ayat (2) Undang-Undang Nomor 22 Tahun 2009 Tentang Lalu Lintas Dan Angkutan Jalan tetap berlaku maka akan menimbulkan kerugian terhadap masyarakat terutama masyarakat Jambi dikarenakan harus mengeluarkan uang untuk menggantikan lampu dan aki sepeda motor karena apabila lampu utama kendaraan sepeda motor dihidupkan tentu akan mempercepat lampu sepeda motor tersebut akan putus dan mempercepat habisnya aki sepeda motor tersebut, sedangkan perekonomian masyarakat Jambi dapat dikategorikan masih rendah dan jika kerugian ini dialami oleh masyarakat kelas bawah maka tidak menutup kemungkinan akan menimbulkan tindak pidana baru seperti pencurian karena membutuhkan uang untuk membeli lampu dan aki sepeda motor.

Kemudian sudah tuh mengemukakan lagi bahwa penggunaan hukum pidana harus pula memperhitungkan prinsip biaya dan hasil. ${ }^{28}$ Dalam hal ini apabila dikaitkan dengan Pasal 107 Ayat (2) Undang-Undang Nomor 22 Tahun 2009 Tentang Lalu Lintas Dan Angkutan Jalan tersebut tentu akan lebih besar biaya pengeluaran yang harus ditanggung oleh pengguna sepeda motor seperti membeli lampu dan aki sepeda motor tersebut karena untuk menghidupkan terus lampu kendaraan sepeda motornya baik di siang hari maupun di malam hari.

Hal yang senada juga terdapat dalam laporan simposium pembaharuan hukum pidana pada bulan Agustus 1980 merekomendasikan bahwa untuk menetapkan suatu perbuatan itu sebagai tindak pidana, perlu memperhatikan kriteria umum, salah satunya adalah Apakah biaya mengkriminalisasi seimbang dengan penghasilan yang akan dicapai. ${ }^{29}$ Jika kita melihat Pasal 107 Ayat (2) Undang-Undang Nomor 22 Tahun 2009 Tentang Lalu Lintas Dan Angkutan Jalan maka dapat disimpulkan bahwa biaya pengkriminalisasian terkait pengguna kendaraan sepeda motor yang harus menghidupkan lampu utama pada siang hari lebih besar daripada hasil yang dicapai karena untuk membuat suatu peraturan perundang-undangan dibutuhkan biaya yang cukup besar, sedangkan apabila dilihat dari hasil yang dicapai dari Pasal 107 Ayat (2) Undang-

\footnotetext{
${ }^{25}$ M. Ali Zaidan, Kebijakan Kriminal, (Jakarta: Sinar Grafik, 2016), halaman 130.

${ }^{26}$ Ibid, halaman 126.

${ }^{27}$ Fathul Achmadi Abby, Pengadilan Jalanan Dalam Dimensi Kebijakan Kriminal, (Jakarta: Jala Permata aksara, 2016),

28 Ibid.

29 Ibid.
} halaman 88. 


\section{Reza Iswanto}

Undang Nomor 22 Tahun 2009 Tentang Lalu Lintas Dan Angkutan Jalan tersebut belum sepenuhnya diterapkan dilapangan baik oleh penegak hukum maupun pengendara sepeda motor itu sendiri.

Kemudian di dalam laporan simposium pembaharuan hukum pidana pada bulan Agustus 1980 menjelaskan bahwa apakah perbuatan-perbuatan itu menghambat atau menghalang-halangi cita-cita bangsa sehingga merupakan bahaya bagi seluruh masyarakat. ${ }^{30}$ Apabila dikaitkan dengan pengendara sepeda motor yang tidak menghidupkan lampu utama kendaraan sepeda motornya di siang hari tidak berbahaya bagi pengendara sepeda motor lainnya. Dengan demikian, sudah jelas bahwa walaupun pengendara sepeda motor tidak menghidupkan lampu utama pada siang hari di jalan raya tidak akan menghalang-halangi cita-cita bangsa karena cita-cita yang diinginkan oleh bangsa Indonesia adalah untuk mewujudkan keamanan, ketertiban, keselamatan dan kesejahteraan masyarakat Indonesia.

Kemudian ditambahkan lagi oleh Sudarto bahwa usaha untuk mewujudkan peraturan-peraturan yang baik, sesuai dengan keadaan dan situasi pada suatu saat. ${ }^{31}$ Dalam hal ini, Pasal 107 Ayat (2) UndangUndang Nomor 22 Tahun 2009 Tentang Lalu Lintas Dan Angkutan Jalan belum sesuai dengan keadaan dan situasi negara Indonesia pada saat ini karena selain tidak bermanfaat untuk menekan tingkat kecelakaan dalam berlalu lintas di jalan raya, keadaan negara Indonesia berbeda dengan negara lain yang cuacanya hanya ada panas dan hujan saja, pada saat cuaca panas, tentu pada saat siang hari masih tampak jelas untuk melihat keadaan di depan pengendara sepeda motor, sedangkan negara lain memang harus menghidupkan lampu utama pada saat siang hari karena di negara lain terdapat 4 musim terutama pada saat musim salju yang harus mewajibkan bagi pengendara sepeda motor untuk menghidupkan lampu utama kendaraan sepeda motornya karena dikhawatirkan salju yang turun akan menutup pandangan pengendara sepeda motor lainnya.

Dengan demikian sudah jelas bahwa Pasal 107 Ayat (2) Undang-Undang Nomor 22 Tahun 2009 Tentang Lalu Lintas Dan Angkutan Jalan tidak memberikan manfaat yang begitu besar bagi masyarakat Indonesia khususnya masyarakat Jambi dalam berkendara sepeda motor di Jalan Raya pada saat siang hari dan juga tidak sesuai dengan keadaan cuaca yang ada di negara Indonesia sehingga tidak diperlukan untuk mewajibkan bagi pengendara sepeda motor menghidupkan lampu utama kendaraan sepeda motornya di siang hari. Untuk itu, kedepannya, di dalam pengaturan lalu lintas, sudah seharunya Pasal 107 Ayat (2) Undang-Undang Nomor 22 Tahun 2009 Tentang Lalu Lintas Dan Angkutan Jalan tersebut dihapuskan dalam Undang-Undang Nomor 22 Tahun 2009 Tentang Lalu Lintas Dan Angkutan Jalan karena tidak memberikan manfaat bagi masyarakat Indonesia terutama masyarakat Jambi.

Dengan demikian, dapat disimpulkan bahwa kebijakan formulasi hukum pidana yang akan datang terkait wajib menyalakan lampu utama pada siang hari dalam Pasal 107 Ayat (2) Undang-Undang Nomor 22 Tahun 2009 Tentang Lalu Lintas Dan Angkutan Jalan adalah penghapusan Pasal 107 Ayat (2) UndangUndang Nomor 22 Tahun 2009 Tentang Lalu Lintas Dan Angkutan Jalan dalam Undang-Undang Nomor 22 Tahun 2009 Tentang Lalu Lintas Dan Angkutan Jalan.

\section{SIMPULAN}

Berdasarkan uraian yang telah dijelaskan dalam pembahasan, maka penulis dapat mengambil kesimpulan sebagai berikut :

1. Latar belakang kebijakan formulasi hukum pidana terkait wajib menyalakan lampu utama pada siang hari dalam Pasal 107 Ayat (2) Undang-Undang Nomor 22 Tahun 2009 Tentang Lalu Lintas Dan Angkutan Jalan adalah Undang-Undang Nomor 14 Tahun 1992 tentang Lalu Lintas dan Angkutan Jalan sudah tidak sesuai lagi dengan kondisi, perubahan lingkungan strategis dan kebutuhan penyelenggaraan Lalu Lintas dan Angkutan Jalan saat ini dan untuk mewujudkan keamanan, keselamatan, ketertiban dan kelancaran berlalu lintas dan Angkutan Jalan serta menekan angka kecelakaan yang selalu meningkat setiap tahunnya.

2. Implikasi dari wajib menyalakan lampu utama pada siang hari dalam Pasal 107 Ayat (2) Undang-Undang Nomor 22 Tahun 2009 Tentang Lalu Lintas Dan Angkutan Jalan adalah lebih besar kerugian yang

\footnotetext{
${ }^{30}$ Ibid.

${ }^{31}$ M. Ali Zaidan, Op.Cit, halaman 130.
} 
didapatkan daripada manfaat yang dihasilkan dari wajib menyalakan lampu utama pada siang hari bagi pengendara sepeda motor pada saat berjalan di jalan raya.

3. Kebijakan formulasi hukum pidana yang akan datang terkait wajib menyalakan lampu utama pada siang hari dalam Pasal 107 Ayat (2) Undang-Undang Nomor 22 Tahun 2009 Tentang Lalu Lintas Dan Angkutan Jalan adalah penghapusan Pasal 107 Ayat (2) Undang-Undang Nomor 22 Tahun 2009 Tentang Lalu Lintas Dan Angkutan Jalan dalam Undang-Undang Nomor 22 Tahun 2009 Tentang Lalu Lintas Dan Angkutan Jalan.

\section{DAFTAR PUSTAKA}

\section{Buku}

Abintoro Prakoso, Sosiologi Hukum, Yogyakarta: Laksbang Grafika, 2017

AR. Sujono, Bony Daniel, Komentar dan Pembahasan Undang-Undang Nomor 35 Tahun 2009 Tentang Narkotika, Jakarta: Sinar Grafik, 2011

Bahder Johan Nasution, Metode Penelitian Ilmu Hukum, Bandung : CV. Mandar Maju, 2016

Barda Nawawi Arief, Bunga Rampai Kebijakan Hukum Pidana Perkembangan Penyusunan Konsep KUHP Baru, Jakarta: Kencana, 2014

Fathul Achmadi Abby, Pengadilan Jalanan Dalam Dimensi Kebijakan Kriminal Jalan, Jakarta: Permata Aksara, 2016

Ishaq, Metode Penelitian Hukum Dan Penulisan Skripsi, Tesis Serta Disertasi, Bandung: Alfabeta, 2017

Kif Aminanto, Politik Hukum Pidana 1 Disparitas Putusan Hakim Dalam Tindak Pidana Korupsi, Jember: Jember Katamedia, 2016

M. Ali Zaidan, Kebijakan Kriminal, Jakarta: Sinar Grafik, 2016

P. Suwardjoko Warpani, Pengelola Lalu lintas dan Angkutan Jalan, Bandung: ITB, 2010

Siswanto S, Politik Hukum Dalam Undang-Undang Narkotika, Jakarta: PT Renika Cipta, 2012

Jurnal

Eko Budi S, Kebijakan Hukum terhadap Tindak Pidana Penangkapan Ikan Secara Ilegal di Perairan Indonesia, Jurnal Wajah Hukum, Volume 2 Nomor 2 (Oktober 2018)

\section{Peraturan Perundang-undangan}

Undang-Undang Nomor 14 Tahun 1992 Tentang Lalu Lintas Dan Angkutan Jalan

Undang-Undang Nomor 22 Tahun 2009 Tentang Lalu Lintas Dan Angkutan Jalan

\section{Internet}

http://jambi.tribunnews.com/2018/11/07/ribuan-pengendara-sudah-terjaring-razia-polisi-hari-ke-delapanoperasi-zebra-2018

https://www.bantuanhukum.or.id/web/implementasi-undang-undang-nomor-22-tahun-2009-tentang-lalulintas-dan-angkutan-jalan-raya/ 